\title{
Interaction between Students' Learning and Early Mathematical Skills to Increase Mathematical Critical Thinking Skills
}

\author{
Yumiati $^{1}$, Yaya S. Kusumah ${ }^{2}$ \\ ${ }^{1}$ Universitas Terbuka, Jakarta, Indonesia., \\ ${ }^{2}$ Universitas Pendidikan Indonesia, Bandung, Indonesia \\ ${ }^{1}$ Correspondence Address;yumi@ecampus.ut.ac.id
}

\begin{abstract}
The aim of this study is to determine the interaction between learning factors (CORE and conventional) and the initial mathematical skills factor (KAM) to increase mathematical critical thinking skills (KBKM) of students. The method used in this study was quasi-experimental with the non-equivalent group pretest-post design. The data analysis used was two-way ANAVA test. The results of the study are (1) There is no interaction between learning factors with KAM factors (2) the improvement students' mathematical critical thinking skills in the CORE (connecting, organizing, reflecting, extending). learning group is higher than the conventional learning group for each KAM group (3) In both learning groups, the improvement of the students' mathematical critical thinking skills in the upper KAM level is higher than the middle and lower KAM level and the improvement in the middle KAM level is higher than the lower KAM level.
\end{abstract}

Keywords: Mathematical Critical Thinking; CORE Learning

\section{INTRODUCTION}

Critical Critical thinking skills are needed to equip someone with success in life (Lee et al., 2016; Dunne, 2015; Olson, 2010; Cottrell, 2005; Schafersman, 1991). Critical thinking helps someone in making a better decisionand choosing the right, effective, or productive information(Happy \& Widjajanti, 2014). The basic purpose of education is to develop the skills to think critically, understand yourself critically, act critically, and independently(Dunne, 2015).Skills that must be provided in the $21^{\text {st }}$ century are critical thinking, communication, collaboration, and creativity (Lee et al., 2016). Thus, some experts state critical thinking skills are important to be possessed by someone including students. Someone who has critical thinking skills does not just receive the information obtained but critically chooses important information that can be used to make conclusions or good decisions. Therefore, critical thinking needs to be developed in learning at school. But in mathematics learning at school, the students' mathematical critical thinking skills were still low.(Kartini, 2011)

Learning that can develop critical thinking skills is learning that involves studentsactively. Classroom learning must provide opportunities for students to make connections between concepts or connections between concepts and problems in everyday life and to recognize patterns to draw conclusions. Students are given responsibility for their own learning process and make them think about what they learn and read. Students must also be given the opportunity to learn independently and learn to respect and trust their own thoughts and ideas. One learning model as mentioned above is CORE learning (connecting, organizing, reflecting, extending). CORE learning combines four important elements of constructivism which connects students' prior knowledge, arranges new material for students, provides opportunities for students to reflect strategically, and provides students with opportunities to expand learning. (Curwen, Miller, White-Smith, \& Calfee, 2010). In CORE learning, thinking 
activities are emphasized to students. Students are required to be able to think critically about the information they get. The learning atmosphere with these characteristics is very possible to direct students to be able to carry out mathematics learning, which in turn, the students' critical thinking skills can increase. There are other factors that are thought to contribute to the improvement of students'mathematical critical thinking skills, one of which is the students' initial mathematical skills factors (KAM). The skills of students to learn new ideas depends on their prior knowledge and existing cognitive structures.(Arends, 1997)

Several previous studies have discussed how the influence of CORE (connecting, organizing, reflecting, extending). learning(Yumiati, 2015), research on the influence of initialskills(Astriani, 2017; Rifqi Hidayat \& Nurrohmah, 2016; Kurniawati, Hartanto, \& Zamzaili, 2017; Lipianto et al., 2013; Widayati, Suyono, \& Rahayu, 2018)as well as research to improve critical thinking skills(Alfi, Sumarmi, \& Amirudin, 2016; Anita, 2015; Fitriana, Yusuf, \& Susanti, 2016; Gazali, Hidayat, \& Yuliati, 2015; Indraningtias, Diah, \& Ariyadi Wijaya, 2017; Jumhariyani, 2016; Pratama \& Prastyaningrum, 2016; Rahmatin, 2013; Yusmanto \& Herman, 2015)However, there is no research that investigates at how CORE learning influences students' mathematical thinking skills in terms of initial skills.

Based on previous research, the renewal of this study focused on the interaction between learning (CORE and conventional) and KAM in improving students' critical thinking skills. So, the purpose of this study is to find out the interaction between learning factors (CORE and conventional) and the initial mathematical skills factor (KAM) on improving students' critical thinking skills (KBKM).

\section{THE RESEARCH METHODS}

This research is a quasi-experimental research with the pretest-post non-equivalent group design(Sugiyono, 2011). To determine the skills of the initial mathematical skills, a pretest was given to classify the students in terms of KAM which follow the rules in Table 1.

Table 1. Criteria for the Initial Mathematical Skills

\begin{tabular}{cc}
\hline KAM Score & KAM Group \\
\hline KAM Score $\varepsilon^{\bar{x}+s}$ & Upper \\
$\bar{x}-s \delta$ KAM Score $\bar{x}+s$ & Middle \\
KAM Score $\bar{x}-s$ & Lower \\
\hline
\end{tabular}

Description:

$\bar{x}=$ Average of KAM test scores of all students

$s=$ Standard deviation of KAM test scores of all students.

The sample of the study was the eight grade students of junior high school in three StateJunior High School in North Jakarta, Indonesia. The schools wereStateJunior High School30, StateJunior High School279, and StateJunior High School277. The instruments used 
were the KAM test,mathematical critical thinking skills test, observation sheets, and interview guidelines.

The data were analyzed using the two-way ANAVA test. If the data is normally distributed, further testing will be theSchefe test. But if the data is not normally distributed, the graph will be used to determine the interaction between learning factors (CORE and conventional) with KAM (upper, middle, and lower). The data tested were mathematical critical thinking skills enhancement data taken from normalized gain scores ( $\mathrm{N}$-gain). The $\mathrm{N}$-gain formula used was:

$$
N-\text { gain }=\frac{\text { Post }- \text { test score }- \text { pretest score }}{\text { Ideal maximum score }- \text { pretest score }}
$$

The criteria of mathematical critical thinking skills improvement use the $\mathrm{N}$-gain criteria proposed by Hake as can be seen in Table 2(Hake, 1998)

Table 2. N-gain Criteria

\begin{tabular}{cc} 
N-gain Criteria & $\mathrm{N}$-gain Interval \\
\hline High & $\mathrm{N}$-gain $>0,7$ \\
Medium & $0,3<\mathrm{N}$-gain $\leq 0,7$ \\
Low & $\mathrm{N}$-gain $\leq 0,3$ \\
\hline
\end{tabular}

\section{THE RESULTS OF THE RESEARCH AND THE DISCUSSION}

The data of N-gain on the students' mathematical critical thinking skillsbased on learning, the KAM group, and the $\mathrm{N}$-gain criteria is presented in Figure 1 below.

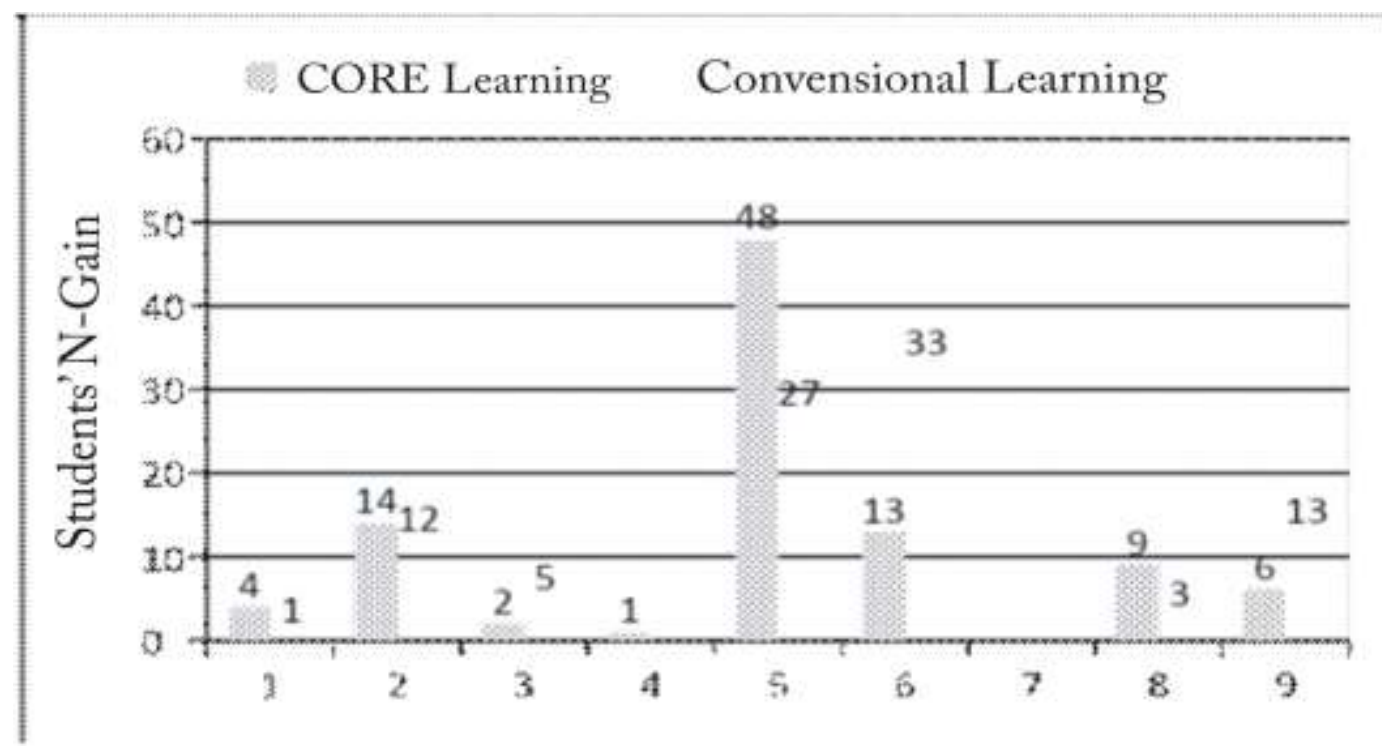

Figure 1.The Number of Students based on the Improvement of Mathematical Critical Thinking Skills, KAM Group, and Learning 
Based on Figure 1, in each KAM group, the number of students with a low category improvement of mathematical critical thinking skillsis more dominant in the conventional learning group than in the CORE learning group. Meanwhile, the number of students with a high or moderate category improvement is more dominant in the CORE learning group than in the conventional learning group. Furthermore, the data on the improvement in the score (N-gain) of mathematical critical thinking skills based on learning and KAM groups are presented in Figure 2 below.

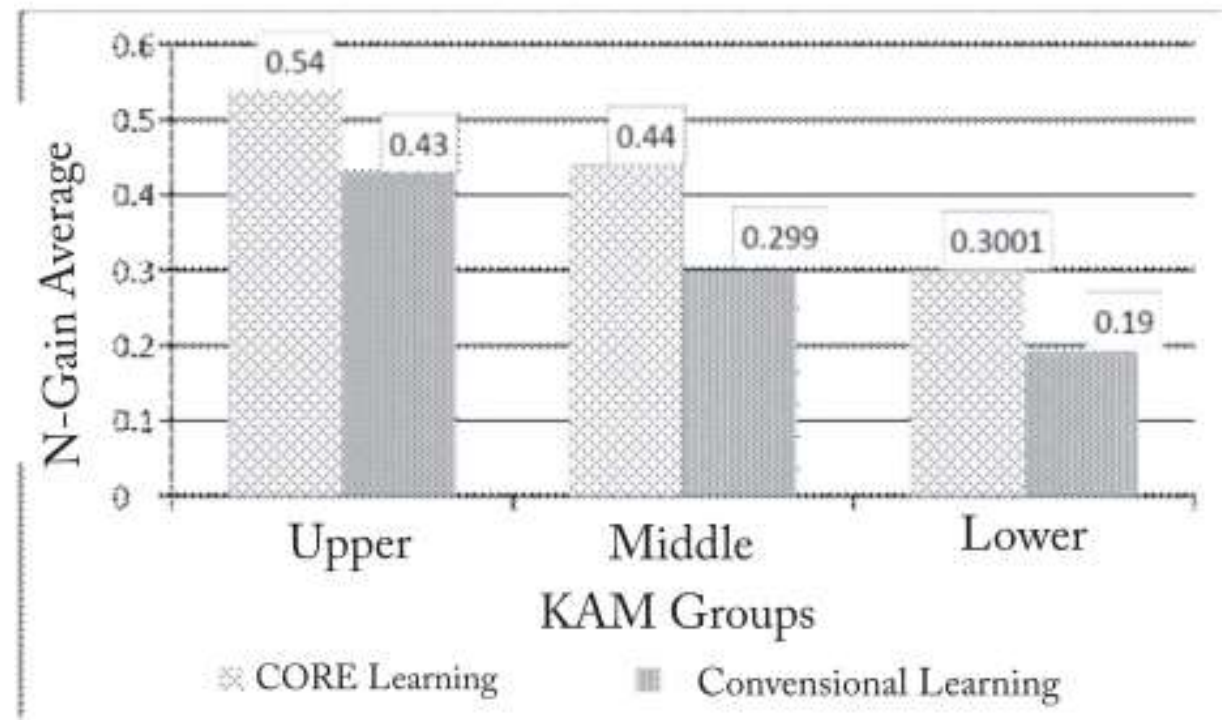

Figure 2. The Average N-gain of Students' mathematical critical thinking skills based on Learningand KAM Groups

Figure 2 shows that the improvement in the mathematical critical thinking skills of CORE learning group is higher than the conventional learning group for each KAM group. The improvement in the students' mathematical critical thinking skills in the upper KAM group is higher than the students in the middle and lower KAM groups and the improvement in the students' mathematical critical thinking skills in the middle KAM group is higher than the students in the lower KAM group. The higher the student's KAM, the higher the increase in mathematical critical thinking skills. Thus, KAM influences the improvement of students' mathematical critical thinking skills.

Based on the N-gain criteria as stated by Hake, the increase in the mathematical critical thinking skills in the CORE learning group is in the moderate category for each KAM group. Meanwhile, the increase in the mathematical critical thinking skills of the conventional learning groups is in the moderate category by only the upper KAM group. The students in the middle and lower KAM groups are in a low category. To see whether there is an interaction effect between learning (CORE and conventional) and KAM (upper, middle, and lower) on the increase of mathematical critical thinking skills must be done by conducting the two-way ANOVA 
testif the data to be tested is normally distributed and the variance is homogeneous. If the normality and homogeneity requirements of the data are not fulfilled, then to see whether there is an interaction effect or not, it is done through the average line graph analysis of the mathematical critical thinking skills on the learning factors and KAM groups. The results of thestudents' mathematical critical thinking skills data on normality testbased on KAM learning and groups are presented in Table 3.

Table 3. Data Normality Test Results of Students' Mathematical Critical Thinking Skills in Both Learning Groups based on KAM

\begin{tabular}{clccc}
\hline \multirow{2}{*}{$\begin{array}{c}\text { Group } \\
\text { KAM }\end{array}$} & Learning & \multicolumn{3}{c}{ Kolmogorov-Smirnov(a) } \\
\cline { 3 - 5 } & Statistics & df & $\begin{array}{c}\text { sig. (2- } \\
\text { direction) }\end{array}$ \\
\hline \multirow{2}{*}{ Upper } & CORE & 0.076 & 20 & $0.200^{*}$ \\
& Conventional & 0.125 & 18 & $0.200^{*}$ \\
\hline \multirow{2}{*}{ Middle } & CORE & 0.110 & 62 & $0.058^{*}$ \\
& Conventional & 0.120 & 60 & 0.033 \\
\hline \multirow{2}{*}{ Lower } & CORE & 0.167 & 15 & $0.200^{*}$ \\
& Conventional & 0.111 & 16 & $0.200^{*}$ \\
\cline { 2 - 5 } & & & &
\end{tabular}

Based on Table 3, the data on the mathematical critical thinking skills and KAM group is not normally distributed. Therefore, the test of the effect of the interaction between learning and KAM on the increase of the mathematical critical thinking skills was done descriptively by using graphics.

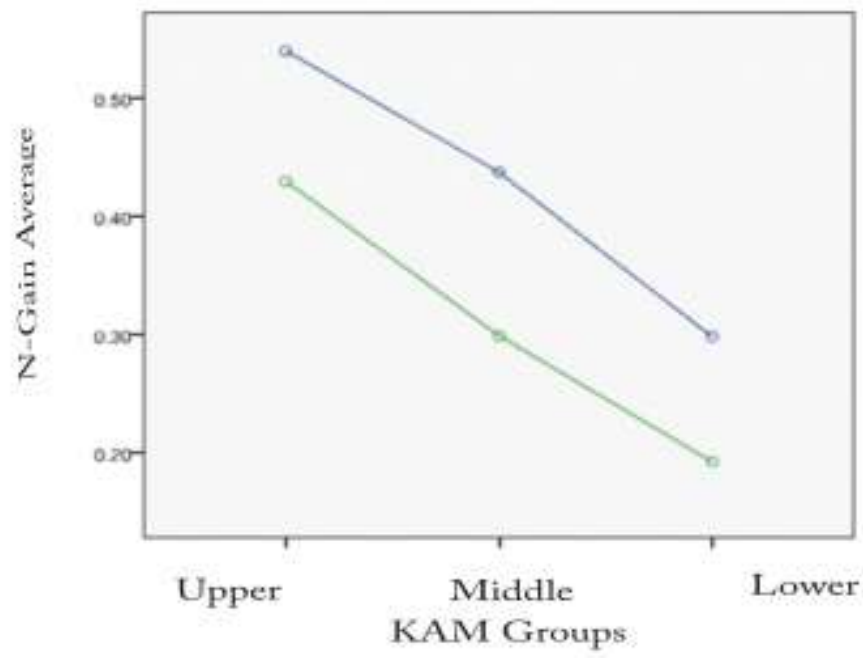

Learning - Converasionat

Figure 3. Graphs of Interaction between Learning and KAMon Student' Mathematical Critical Thinking Skills Improvement

Based on Figure 3, the following illustrations and conclusions are obtained: 
a) The line graph of the average increase in the mathematical critical thinking skills of CORE learning group is above the line graph of the average mathematical critical thinking skills increase in the conventional learning group. This means that the increase ofthe mathematical critical thinking skillsin the CORE learning group is higher than the conventional learning group for each KAM group. Thus, it can be concluded that CORE learning is a learning factor that has a greater influence on the increase in students' mathematical critical thinking skills than conventional learning for each KAM group.

b) In both study groups, the increase in the students' mathematical critical thinking skills in the upper KAM group is better than the students in the middle and lower KAM groups. Likewise, the increase in the students' mathematical critical thinking skills in the middle KAM group is better than the lower KAM group. Thus, both (CORE and conventional) learning do not change the KAM order towardthe increase in mathematical critical thinking skills. This also illustrates that the upper KAM group has a greater influence on the increase in student' mathematical critical thinking skills compared to the middle and lower KAM groups. Likewise, the middle KAM group has a greater influence on the increase in the students' mathematical critical thinking skills than the lower KAM group.

c) The line graph of the average increase in the students' mathematical critical thinking skills in the CORE learning group and the line graph of the average mathematical critical thinking skills increase in conventional learning group do not overlap. This shows that there is no interaction between learning factors and KAM to increase students' mathematical critical thinking skills if this factor is used simultaneously. Thus, the effectiveness of the application of the learning model does not depend on KAM in improving students' mathematical critical thinking skills.

The results of the study indicate that there is no interaction between learning factors (CORE and conventional) and KAM factors (upper, middle, lower) to increase the students' mathematical critical thinking skills if these factors are used simultaneously. This means that the KAM factors of students and learning do not jointly influence the increase of mathematical critical thinking skills and the effectiveness of applying the learning model does not depend on the KAM groups. This means that CORE and conventional learning can be applied in each KAM group. In addition, the increase in mathematical critical thinking skills of CORE learning group is better than the conventional learning group. So, it can be concluded that CORE learning is a learning factor that has a large influence on improving student's mathematical critical thinking skills compared to conventional learning. The results of this study are in accordance with the research by Hidayat which conclude that there is no interaction between learning (REACT and conventional learning) with KAM groups in improving critical thinking skills.(R Hidayat, 2010)

The results also showed that the number of students with a low increase in the mathematical critical thinking skillsis dominantly in the conventional learning group compared to the CORE learning group. Meanwhile, the number of students with a medium or high increase in the mathematical critical thinking skillsare dominant in the CORE learning group than in the conventional learning group. The increase in the students' mathematical critical thinking skills in the CORE learning group is in the medium category for each KAM group. The increase ofthe 
students' mathematical critical thinking skills in conventional learning group in the medium category is only in the upper KAM group while students in the middle and lower KAM groups are in a low category. The results of this study indicate the strong influence of CORE learning in improving students' mathematical critical thinking skillscompared to conventional learning. According to Curwen, the CORE learning steps are connecting, organizing.reflecting, and extending stages. (Curwen et al., 2010). The strong influence of CORE learning in improving students' mathematical critical thinking skillscan be explained through CORE learning steps, namely in the early stages, such as research by Yumiyati that reveals that the teacher activates students' initial knowledge related to the material to be studied. (Yumiati, 2015). The activity of activating the initial knowledge can evaluate students' understanding of past knowledge. Connection of old information and new information and between mathematical concepts provide training for students to connect these concepts. Giving problems in the organizing stage requires students to explore their solutions independently or in groups. Exploration activities can improve the aspects of students' mathematical critical thinking skills, namely the aspects of connecting and analyzing.

In thereflecting stage, the teacher and students review the things that have been done in learning. Students must show their work by displaying it in front of the class. The following are the results of student discussion to find the relationship of the sum of the squares of the shortest and the longest side square of the taper and blunt triangles.

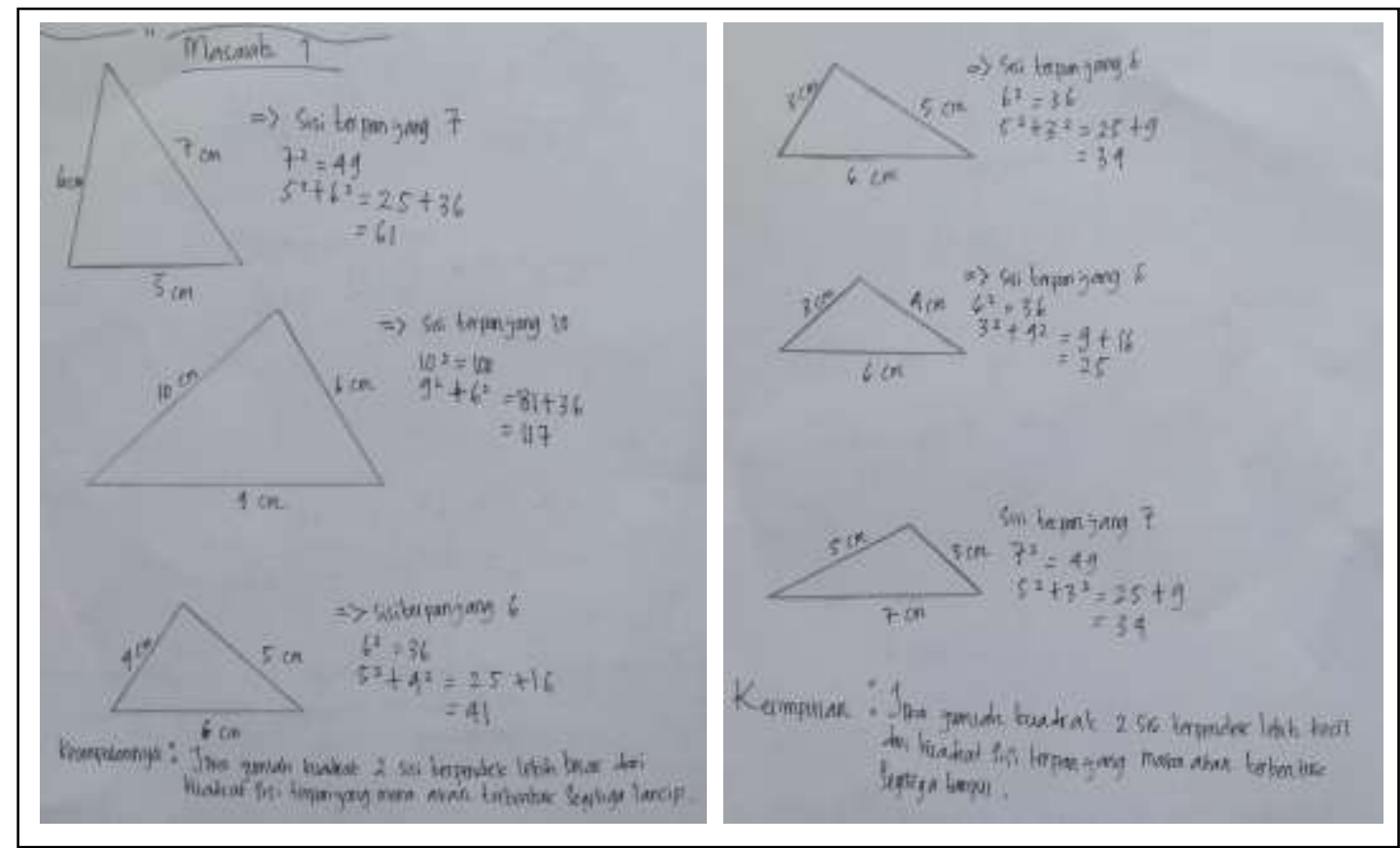

Figure 4. Students' Answers In Finding the Relationship between Blunt and Taper Triangles

Through the results of their work, the students can analyze and evaluate the results they have obtained in theorganizingstage together with other students. Thus, aspects of analyzing and evaluating can be developed. 
The extended problems at theextending stage require the students to think critically because they contain activities that connect concepts, analyze problems, evaluate the accuracy of the application of concepts and principles that have just been studied on the problem and sometimes require good evidentiary skills if the problem needs proof.

All of these activities are a form of critical thinking activities, namely the skills and disposition to combine prior knowledge, mathematical reasoning, and cognitive strategies to generalize, prove, or evaluate situations or unfamiliar mathematical problems in a reflective way. Likewise, as revealed by O'Daffer \& Thornquist, mathematical critical thinking is a process of using the skills to think effectively to help a person compile, evaluate, and apply decisions about what is believed or done. If this is done continuously, the students' mathematical critical thinking skills will develop and improve.(Rohaeti, 2008)

Another finding in this study is that the increase of the students' mathematical critical thinking skills in the upper KAM group is better than students in the middle and lower KAM groups and the increase of mathematical critical thinking skills in the middle KAM group is better than students in the lower KAM group in both learning groups. This shows that the initial skills factor has a significant effect on the improvement of students' mathematical critical thinking skills. This result is consistent with previous research which says that students' skills to learn new ideas depends on their prior knowledge and existing cognitive structures. Likewise, as expressed by Piaget that understanding is a process of intellectual adaptation where new experiences and ideas are interacted with what is already known to form new understanding structures.(Suparno, 2001)

\section{CONCLUSION AND SUGGESTION}

Based on the results of the study, it can be concluded that (1) there is no interaction between learning factors with KAM factors, (2) the increase of mathematical critical thinking skills in CORE learning group is higher than conventional learning group for each KAM group, (3) in both study groups, the increase in mathematical critical thinking skills of upper KAM group is higher than the middle and lower KAM groups and the increase in the middle KAM groupis higher than the lower KAM group. These results indicate that CORE learning has a strong on conventional learning in improving students' mathematical critical thinking.

The suggestions that can be given to the next researcher are to be able to examine the interaction between learning factors with other skills factor that exist in students so that more varied research can be productive and it is recommended for the teachers and prospective teachers to apply CORE learning in improving students' mathematical critical thinking skills.

\section{REFERENCES}

Alfi, C., Sumarmi, \& Amirudin, A. (2016). Pengaruh Pembelajaran Geografi Berbasis Masalah Dengan Blended Learning Terhadap Kemampuan Berpikir Kritis Siswa SMA. Jurnal Pendidikan: Teori, Penelitian, Dan Pengembangan, 1(4), 597-602.

Anita, I. W. (2015). Pengaruh Motivasi Belajar Ditinjau Dari Jenis Kelamin Terhadap Kemampuan Berpikir Kritis Matematis Mahasiswa. Jurnal Ilmiah UPT P2M STKIP 
Siliwangi, 2(2), 246-251.

Arends, R. (1997). Classroom Instructional Management. New York: The Mc Graw-Hill Company.

Astriani, L. (2017). Pengaruh pembelajaran reciprocal teaching terhadap kemampuan pemahaman konsep matematika ditinjau dari kemampuan awal matematika siswa. Jurnal Pendidikan Matematika Dan Matematika, 3(1), 77-85.

Cottrell, S. (2005). Developing Effective Analysis and Argument. Library.

Curwen, M. S., Miller, R. G., White-Smith, K. A., \& Calfee, R. C. (2010). Increasing Teachers' Metacognition Develops Students' Higher Learning during Content Area Literacy Instruction:. Issues in Teacher Education, 19(2), 127-151.

Dunne, G. (2015). Beyond critical thinking to critical being: Criticality in higher education and life. International Journal of Educational Research, 71, 86-99.

Fitriana, D., Yusuf, M., \& Susanti, E. (2016). Pengembangan Lembar Kerja Siswa Menggunakan Pendekatan Saintifik Untuk Melihat Berpikir Kritis Siswa Materi Perbandingan. Jurnal Pendidikan Matematika, 10(2), 1-17.

Gazali, A., Hidayat, A., \& Yuliati, L. (2015). Efektivitas Model Siklus Belajar 5E Terhadap Keterampilan Proses Sains dan Kemampuan Berpikir Kritis Siswa. Jurnal Pendidikan Sains, 3(1), 10-16.

Hake, R. R. (1998). Interactive-engagement versus traditional methods: A six-thousand-student survey of mechanics test data for introductory physics courses. American Journal of Physics, 66(1), 64-74. https://doi.org/10.1119/1.18809

Happy, N., \& Widjajanti, D. B. (2014). Keefektifan PBL Ditinjau Dari Berfikir Kritis Dan Kreatif Matematis, Serta Self-esteem Siswa SMP. Jurnal Riset Pendidikan Matematika, $1(1), 48-57$.

Hidayat, R. (2010). Pembelajaran Kontekstual dengan Strategi REACT dalam Upaya Pengembangan Kemampuan Pemecahan Masalah, Berpikir Kritis, dan Berpikir Kreatif Matematis Mahasiswa Bidang Bisnis. Disertasi pada Universitas Pendidikan Indonesia.

Hidayat, R., \& Nurrohmah. (2016). Analisis Peningkatan Kemampuan Pemahaman Konsep Matematis Siswa MTs Lewat Penerapan Model Pembelajaran Problem Based Learning Berbantuan Software Geogebra Berdasarkan Kemampuan Awal Matematika. JPPM, 9(1), $12-19$.

Indraningtias, A., Diah, \& Ariyadi Wijaya. (2017). Pengembangan Perangkat Pembelajaran Berbasis Pendekatan Matematika Realistik Materi Bangun Ruang Sisi DatarBerorientasi Pada Kemampuan Berpikir Kritis Siswa Kelas VIIISMP. Jurnal Pendidikan Matematika, 6(5), 1-10.

Jumhariyani. (2016). Pengaruh Metode Penemuan Terbimbing Dan Kemampuan Berpikir Kritis Terhadap Kemampuan Matematika Siswa Kelas IV SD Sekecamatan SetiaBudi Jakarta Selatan. Jurnal Pendidikan Dasar, 7(1), 62-73. 
Kartini. (2011). Peningkatan Kemampuan Berpikir Kritis dan Kreatif serta Belief Matematis Siswa Sekolah Menengah Atas melalui Pembelajaran Inkuiri Model Alberta. Disertasi pada Universitas Pendidikan Indonesia.

Kurniawati, E., Hartanto, \& Zamzaili. (2017). Pengaruh Model Pembelajaran ARIAS INTEGRATIF Dan Kemampuan Awal Dalam meningkatkan Pemahaman Konsep Dan Pemecahan Masalah Matematika Siswa SMP Di Kepahiang. Jurnal Pendidikan Matematika Raflesia, 2(2), 174-187.

Lee, H., Parsons, D., Kwon, G., Kim, J., Petrova, K., Jeong, E., \& Ryu, H. (2016). Cooperation begins: Encouraging critical thinking skills through cooperative reciprocity using a mobile learning game. Computers and Education, 97, 97-115.

Lipianto, D., Budiarto, M. T., Matematika, J., Surabaya, U. N., Matematika, J., \& Surabaya, U. N. (2013). Analisis kesalahan siswa dalam menyelesakan soal yang persegi dan persegipanjang berdasarkan taksonomi solo plus pada kelas vii. Mathedunesa, 2(1).

Olson, K. L. (2010). The Craftsmanship of Critical Thinking. Dissertation on Argosy University.

Pratama, H., \& Prastyaningrum, I. (2016). Pengaruh Model Pembelajaran Project Based Learning Berbantuan Media Pembelajaran Pembangkit Listrik Tenaga Mikrohidro Terhadap Kemampuan Berpikir Kritis. Jurnal Penelitian Fisika dan Aplikasinya (JPFA), 6(2), 44-50.

Rahmatin, D. N. (2013). Profil berpikir kritis mahasiswa pendidikan matematika dalam memecahkan masalah nilai dan vektor eigen ditinjau dari pemetaan kemampuan aljabar. Gamatika, 3(2), 101-109.

Rohaeti, E. E. (2008). Pembelajaran dengan Pendekatan Eksplorasi untuk Mengembangkan Kemampuan Berpikir Kritis dan Kreatif Matematis Siswa Sekolah Menengah Pertama. Disertasi pada Universitas Pendidikan Indonesia.

Schafersman, S. D. (1991). An Introduction to Critical Thinking. Critical Thinking, 1-13.

Sugiyono. (2011). Statistik untuk Penelitian. Bandung: Alfabeta.

Suparno, R. (2001). Teori Perkembangan Kognitif Jean Piaget. Yogyakarta: Kanisius.

Widayati, Suyono, \& Rahayu, W. (2018). Pengaruh Model Pembelajaran Berbasis Penemuan Terhadap Kemampuan Berfikir Kritis Matematis Dan Self Concept Dengan Mengontrol Kemampuan Awal Peserta Didik Kelas VII SMP. JPP, 11(1), 94-104.

Yumiati. (2015). Application of Connecting, Organizing, Reflecting, and Extending (CORE) Learning to Improve Critical Thinking Skills in Mathematics. In The 2015 International Seminar on Education. Universitas Bengkulu, 16 - 18 Januari 2015.

Yusmanto, \& Herman, T. (2015). Pengaruh Penerapan Model Pembelajaran Discovery Learning Terhadap Peningkatan Kemampuan Berpikir Kritis Matematis Dan Self Confidence Siswa Kelas V Sekolah Dasae. EduHumaniora, 7(2), 140-151. 